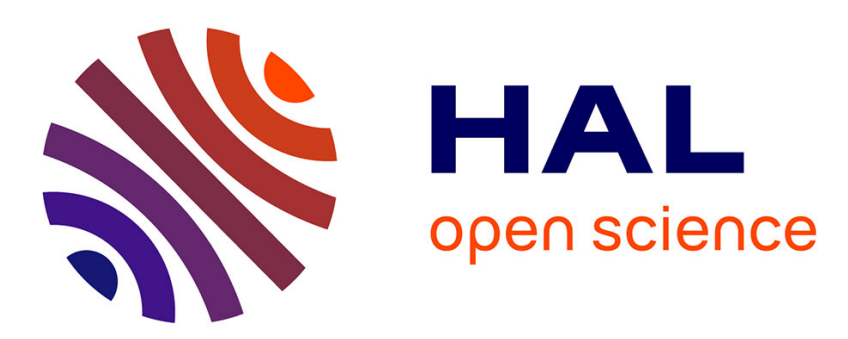

\title{
Interacting individuals and organizations : a case study on cooperations between firms and research laboratories
}

Michel Grossetti, Marie-Pierre Renée Bes

\section{To cite this version:}

Michel Grossetti, Marie-Pierre Renée Bes. Interacting individuals and organizations: a case study on cooperations between firms and research laboratories. 5th Workshop on Economics with Heterogeneous Interacting Agents (WEHIA), Jun 2000, Marseille, France. 343 p. halshs-00476922

\section{HAL Id: halshs-00476922 \\ https://shs.hal.science/halshs-00476922}

Submitted on 27 Apr 2010

HAL is a multi-disciplinary open access archive for the deposit and dissemination of scientific research documents, whether they are published or not. The documents may come from teaching and research institutions in France or abroad, or from public or private research centers.
L'archive ouverte pluridisciplinaire HAL, est destinée au dépôt et à la diffusion de documents scientifiques de niveau recherche, publiés ou non, émanant des établissements d'enseignement et de recherche français ou étrangers, des laboratoires publics ou privés. 


\section{Interacting individuals and organizations : a case study on cooperations between firms and research laboratories 1}

in Alan Kirman et Jean-Benoît Zimmermann, Economics with heterogeneous interacting agents, Springer, pp.287-302

\section{Introduction}

The question of which kind of entities are really interacting is specifically central and difficult in the study of cooperations between research laboratories and firms, because these cooperations involve various kinds of agents.

In France, a contract of cooperation between a research laboratory and a firm is signed both by the firm and by a big research organization like a university or the CNRS. The contract generally mentions the name of the research laboratory, as it is defined by the university or the CNRS (the french national center for scientific research), and also the name of the research leader. For the research side, there are three different levels of action : the liable organization ; the research laboratory as an internal organization inside the university or the CNRS ; and at last a single researcher. It is also known (Amiot, 1996) that there is fourth level, which is the small research team (a dozen of researchers) working with the scientific leader. For the firm, there are also several levels, especially for a group : the group ; a local establishment really cooperating with the laboratory ; a specific team within this establishment ; and at last, the industrial leader of the cooperation.

Which is the appropriate scale of analysis for the study of this kind of interactions between heterogeneous agents ? What are the agents really interacting (individuals, small teams, organizations) ? What are the processes by which decision making shifts from a level to another?

We will address these questions on the basis of the results of an empirical study of cooperations between firms and CNRS laboratories in the field of engineering, conducted in order to understand the genesis of cooperations. For that, we have reconstructed 130 stories -

\footnotetext{
1 This paper presents the first results of a study made with the support of the CNRS program "Les enjeux
} 
from the beginning to the end - of cooperations (with a contract at one time, but not necessary during all of the story), involving 27 scientific leaders, 19 laboratories and 81 industrial partners (firms or interprofessionnal organizations). These stories were reconstructed by using interviews with the participants, in the laboratory and in the firm. A minimum of two interviews (and a maximum of five) were used for each story. The stories have various duration (from six month to forty years) and take place in various fields (computing, electronics, fluid mechanics, chemical engineering, etc.) and various institutional contexts (existence of a technical milieu with associations or government organizations). The questions were mainly focused on the genesis of any cooperation and also on the processes of routinization and institutionnalization resulting in a shift of the level of action and relationship (shifting from individual level to the organizational one for example). We will discuss the various kinds of meeting using the notions of embeddedness (Polanyi, Granovetter, White), and decoupling (White), and more generally the theory of Harrison White's "Identity and Control" (1992).

We will discuss the following questions on the basis of our empirical study :

What units of interaction are relevant in that kind of cooperation ? We make the general hypothesis that the relevant action units can change in time from the individual level to the organizational level or conversely in becoming personal after as start in an interorganizational frame. Our second hypothesis on this question is that the relationship between scientific organizations and firms form an exchange sphere partially embedded in other activity spheres : the higher education system, the labour market and less importantly the non professional activities..

This questions and hypothesis are especially involved in the analysis of spatial proximity effects, that is the fact that they are more probable if the partners are located in the same urban $\operatorname{area}^{2}$. The two main explanations of spatial proximity effects are, on the one hand, the constraint of face to face interaction for tacit knowledge exchange (Zucker, Darby and Armstrong, 1994, repeated by Callon et Foray, 1997), and on the other hand, the effect of personal networks in the relations between organizations (Powell et Brantley, 1994 ; Saxenian, 1994 ; Grossetti, 1995). Here, the choice between analysis units (organizations, 
individuals, connection between the two) is a crucial point. We make the hypothesis that the proximity effects are explained by the embeddedness of the relationship between organizations within interpersonal, professional or non professional networks.

\section{Our theoretical frame : Embeddedness and decoupling}

It seems to us that the theoretical framework proposed by White (1992), although we adopt only some of his ideas ${ }^{3}$, is helpful in clarifying some aspects of the problem of choice on the appropriate action unit in a collaboration context. First, it doesn't postulate as a start the superiority of one particular action unit (individual, firm or state) but considers the problem of constructing identities in interaction confronted with the actions of others identities. In some cases, the germane action units will therefore be the individuals and in other cases, the collective entities. An identity has a story and can grow or dissolve itself in the interaction dynamics. Second, the embeddedness concept developped by White is more complicated this one that was made famous by Granovetter. For White, the embeddedness is a process with a reverse, the decoupling, that is the interactions abstraction in some particular institutions and in some regulatory ways, which he calls styles. So, the embeddedness and decoupling processes are very similar to the framing/overflowing notions, as defined by M. Callon (1999) after Goffman ; with the framing process corresponding to the decoupling and the overflowing to the embeddedness. As Callon suggests, it's possible to link the question of framing/overflowing or decoupling/embeddedness with the notions of market internalization and externalities, as developed by the economists. A synthesis of these correspondences can be shown in the following table:

\begin{tabular}{|l|l|l|}
\hline Conceptual frame & Autonomy of on exchange & dependence upon other \\
& sphere & exchange spheres or forms \\
\hdashline White / Granovetter & decoupling & embeddedness \\
\hdashline Callon & framing & overflowing \\
\hdashline standard economist Theory & internalization & externalities \\
\hline
\end{tabular}

\footnotetext{
2 Jaffe, 1989 ; Audretsch et Feldman, 1996 ; Zucker, Darby et Armstrong, 1994 ; Estades, Joly et Mangematin, 1995 ; Grossetti, 1995, etc.
} 
The analysis framework we adopt is similar to White's and considers two action levels, the organizations level and the individuals level, and three kinds of embeddedness/decoupling process : the first type corresponds to the relationship embeddedness between organizations within inter-individuals networks (example : a relationship between individuals, give rise to an exchange between their respective organizations). The second type is the embeddedness of inter-individual relationship in collective contexts, that is the fact that personal relationships more often develop within collective frames before becoming autonomous from those frames (for example, two doctorates from the same scientific team, have stinted an individual relationship in this collective frame, and keep contact although one has joined a commercial firm and the other has stayed in the laboratory).

The third kind, which results from the first two on a wider level in exchanges spheres, is the embeddedness between one sort of exchange (the relationship between public research and firms) within another sort of exchanges (the work market for example).

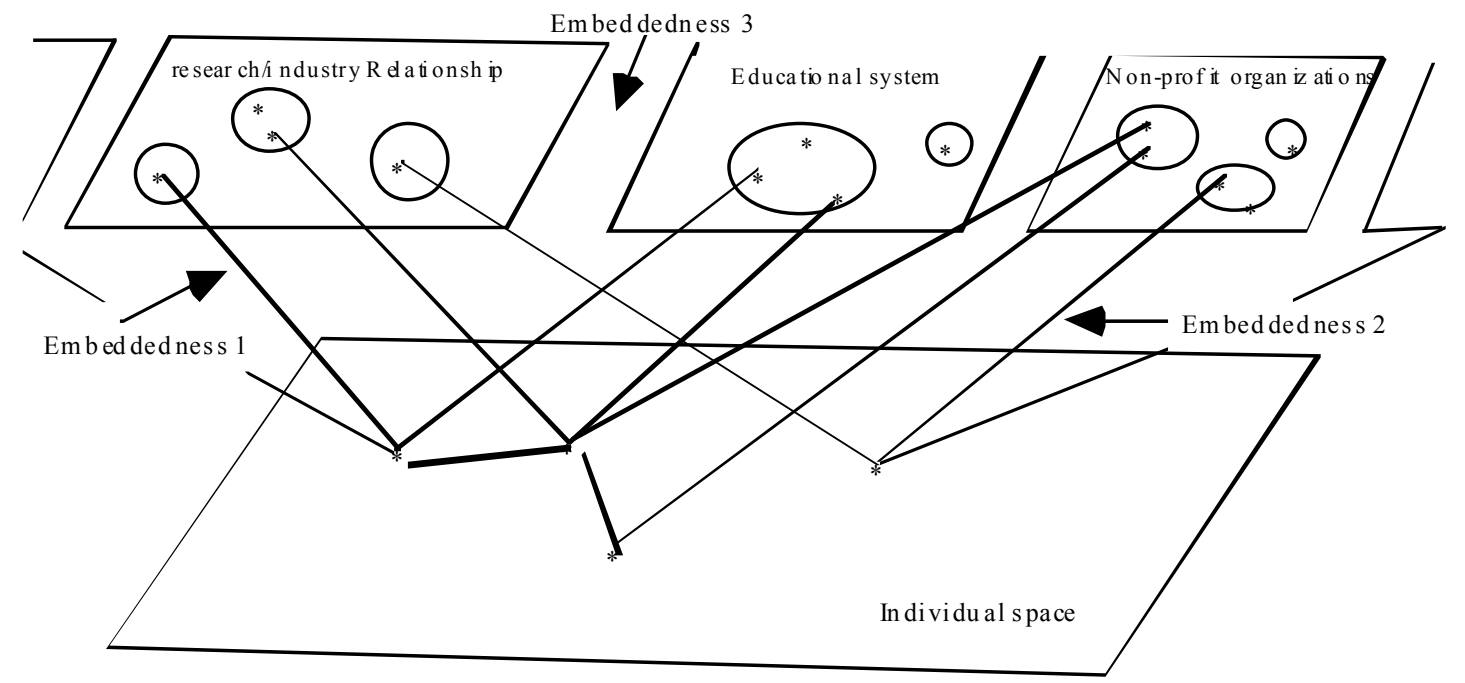

tw o spa ces, th ree kind s of e mbeddedn ess

The issue of the autonomy of this particular exchange sphere is an important point of discussion. Some authors defend the thesis of the autonomy of cooperations between firms and research laboratories, due to the specific nature of knowledge in R\&D activities. Som others defend the embeddedness thesis, in which this sphere partially depends on other

\footnotetext{
3 Thanks to Alain Degenne for his help in the comprehension of theorical framework elaborated by
} 
spheres (labour market, educational system) or (horresco referens for some) on nonprofessional social activities. Raising the issue of which of the action units are considered, allows to separate between two problems which are often mixed up : the problem of the embeddedness between activities spheres and, the problem of the embeddedness between organization relationships within interindividuals exchange.

\section{Some Collaborations Stories}

We have chosen to study the collaborations between some CNRS research laboratories within the "Engineering Sciences" department, where the public research has to prove also a mission in firms support. We analysed more than a hundred collaborations, which at some time or the other were based on a contract.

The method consists at first, in collecting information from the CNRS data base "protocole"4 which lists all the contracts signed between the CNRS units and outside partner (about 14000 contracts signed with firms between 1987 and 1998). We selected some researchers who were scientifically responsible for some of these contracts and we asked them to describe several collaboration experiences in order to collect some data on the genesis and on the evolution of the collaboration. In fact, we not only insisted on the relationship genesis between organizations but we also tried to go back in time to the prior individual. Each story collected from one researcher was completed by interviews made with industrial partners or other participants (other researcher, doctorate financed in the frame of this collaboration, help given by employees from external organizations, colleague, and so on).

The basic unit, the history of which we have been trying to reconstruct is not the contract, as it appears in the CNRS information data, but the collaboration, which may go through a succession of contracts as well as non-contractual periods or different institutional forms (a common research laboratory for example). To define the beginning and the end of a story, we used a criteria of relational continuity, that is the fact that the contacts between the teams, in the research laboratory and in the firm, keep on going, even if the people change or if the

\footnotetext{
Harrison White trough a working paper very clear not yet published.

${ }^{4}$ Thanks to Joseph Baixeras and to the CNRS relationship firms service for allowing us to access to some data information.
} 
content evolves. The important fact is the opportunity to observe some intermediary operation between the individuals, involved in both organizations.

We realized 27 initial interviews with researchers, which generated 130 stories, which themselves were completed with 119 interviews (73 with industrial partners, 46 with other researchers or participants). The researchers initially questioned belong to teams located in Toulouse (11), Bordeaux (5), Montpellier (3), Clermont-Ferrand (2) and Grenoble (6); most of the SPI (sciences for Engineering) are represented : electrotechnics (1) electronics (7), automatics and robotics (3), computing (5), chemical engineering (4), fluid mechanics (7).

The 130 relationships involve 81 partners, in which 38 major companies ( 73 relationships), 35 small firms (38 relationships) and 8 are public organizations of technological research (CNES, CNET, and so on) which we choose to include because they played the part of true industrial partners in the stories collected. $36 \%$ of these relationship are located in the same region (the research and the firm are located in the same region), 38\% associate a provincial laboratory and a firm located in the Paris region and $26 \%$ a research laboratory and a partner from another region or country.

\section{Which explanation of spatial proximity?}

The two hypothesis that we presented above are very different. In the first one, the proximity effects are active all along the cooperations, while in the second one, they are active only during the genesis of the cooperations. In the first one, the relation can involve different individuals for each organization, as far as they can have face to face interactions, while in the second one, a relation can disappear if the involved individuals are substituted by other people. In the first one, the relevant unit of action remains the firm (a firm can choose to move to get nearer of a partner in order to facilitate tacit knowledge exchange) while in the second one, there are two kinds of units of action, the organizations and the individuals. In the first one, the relation is decoupled or framed, autonomous from the flow of personal interactions outside the involved organizations. In the second one, on the contrary, the relation can be embedded in this flow, at least at the beginning. In the first one, we can remain in the framework of innovation economy while in the second one, we need to use a sociological approach. 
After more than one year or inquiry, we have totally dropped the first hypothesis and we have several new reasons to advocate the second one.

\subsection{The constraint on tacit knowledge exchange doesn't explain proximity effects}

Let's recall that the tacit knowledge explanation for proximity effects, which is advocated by several authors, postulates that people from firms must have the possibility to go to the laboratories in order to get researchers tacit knowledge, and that is what makes local relations more likely.

We have seen no cases when engineers or firms members had regularly gone to their cooperating laboratory more than the 3 or 4 usual yearly coordination meetings, a rhythm that practically doesn't vary and that makes no difference between local cooperations and the other ones. When a cooperation needs considerable exchange, which is not always true, there generally is a PHD student who works at different periods either in the laboratory either in the firm. When the partners are far from each other, the technical problems can be solved by specific methods like the making of a double model of the studied system in the laboratory and in the firm (in electrical engineering for example).

There is another reason to refuse tacit knowledge explanation : in our data we have no correlation between local cooperations and the contents of this cooperations as we coded it ${ }^{\mathrm{i}}$. It doesn't mean that there is no tacit dimension in these cooperations but it doesn't explain the proximity effect ${ }^{5}$ s.

\subsection{The ways that cooperations begin}

In a study of laboratories from agronomics national institute or research (INRA) using questionnaires, (Estades, Joly et Mangematin, 1996) conclude that there are three logics of beginning of cooperations between laboratories and firms : a "proximity" logic, when local milieu and personal networks are central ; a "market" logic when a firm have defined a precise

\footnotetext{
5 We think about knowledge on the partner behaviour, on the scientific disciplines concerned by thecooperation, on habits to cooperate, and son on.
} 
problem and look for the best partner by formal ways (journals, etc.) ; the "club" logic, when there is another organization that put the partners together. We will see that local relations doesn't necessary come from personal networks and that personal networks can result in non local relations. We will also see that it is not necessarily the firm that takes the initiative to seek for a partner. It can be the laboratory. At last, the third organization can be there without being at the origin of the relation. We have made three categories of cooperations genesis that don't take into account the fact that cooperation are local or not : the network logic ; the institutionnal logic and the market logic.

\subsubsection{The "network" logic}

As we expected it, a great part of the cooperations (48 cases, $44 \%$ ) have their origin in a chain of personal ties between the two leaders who will later sign the contract. In each case, it is possible to isolate one key personal tie that explains the making of the cooperation. It can be classified in two sub-categories of network logics, the first one that involves professional relations (former co-workers, former students of the same courses, professor and former student), and the second one, that involves private relations (kin ties, or friend ties). The two logics define two different kinds of embeddedness : in the first case, cooperations between research laboratories and firm are embedded in the teaching activity of universities or engineering schools, while in the second case, it is a much more general embeddedness. The following table shows that in our stories it seems to be the first kind of embeddedness that dominates, particularly the relations that take their origins in the teaching activity and the labor market. However, non professional ties are not rare, and this shows that even research, which is a so specialized activity, can be embedded for a part in non professional relations.

\section{Categories of personal ties used in network logics of connexion}

\begin{tabular}{|l|l|l|c|}
\hline $\begin{array}{l}\text { Key ties } \\
\text { categories }\end{array}$ & $\begin{array}{c}\text { Key ties sub- } \\
\text { categories }\end{array}$ & $\begin{array}{c}\text { Pumber } \\
\text { network } \\
\text { connections }\end{array}$ & $\begin{array}{c}\text { Proportion of } \\
\text { connections } \\
\text { total (among } \\
110 \text { coded } \\
\text { stories ) }\end{array}$ \\
\hline
\end{tabular}




\begin{tabular}{|c|c|c|c|c|}
\hline $\begin{array}{l}\text { Non } \\
\text { professional } \\
\text { ties }\end{array}$ & $\begin{array}{c}\text { Kinship, } \\
\text { childhood (5) } \\
\text { Non } \\
\text { professional } \\
\text { organizations, } \\
\text { friends (4) }\end{array}$ & 9 & $19 \%$ & $8 \%$ \\
\hline $\begin{array}{l}\text { Teaching } \\
\text { relations }\end{array}$ & $\begin{array}{c}\text { Former } \\
\text { students (9) } \\
\text { Teacher/ } \\
\text { former } \\
\text { student }(10)\end{array}$ & 19 & $40 \%$ & $17 \%$ \\
\hline $\begin{array}{l}\text { Professional } \\
\text { relations }\end{array}$ & $\begin{array}{l}\text { Former co- } \\
\text { workers in } \\
\text { research (12) } \\
\text { Former co- } \\
\text { workers in } \\
\text { firms }(8)\end{array}$ & 20 & $41 \%$ & $19 \%$ \\
\hline Total & & 48 & $100 \%$ & $44 \%$ \\
\hline
\end{tabular}

We must insist on the fact that this embeddedness is limited to the genesis of the cooperations. A cooperation which takes its origin in personal networks can move to a more formal way, involving new people and develop in a way that keeps no traces of its origin. In that case, the relation is decoupled from its initial context.

The making of cooperations between organizations on the basis of personal ties is a kind of embeddedness that operates a move in the scale of action since what is happening at the level of organization is the result of logics from another level of action (individuals and their relations).

\subsection{2. "Institutional" logics}

In a part of the stories $(20,18 \%)$, the cooperation between a laboratory and a firm result from the participation of the two leaders in a meeting organized by an third organization, from national or local administration. For example, a firm executive and a researcher that can influence their organizations and don't know each other are invited to participate in an expert committee. To participate in such a group (generally from 10 to 30 persons) that have to give collective advice and to make collective decisions implies interactions that can result in bilateral cooperations projects. 


\section{Institutional connections}

\begin{tabular}{|c|c|c|c|c|}
\hline $\begin{array}{l}\text { Categories of } \\
\text { institutions }\end{array}$ & Sub-categories & Number & $\begin{array}{l}\text { Proportion of } \\
\text { institutional } \\
\text { connections }\end{array}$ & $\begin{array}{c}\text { Proportion of } \\
\text { all } \\
\text { connections(am } \\
\text { ong } 110 \text { coded } \\
\text { stories) }\end{array}$ \\
\hline National level & $\begin{array}{c}\text { National } \\
\text { administration( } \\
\text { CNRS } \\
\text { committees, } \\
\text { etc.) (11) } \\
\text { State } \\
\text { technological } \\
\text { industry (EDF, } \\
\text { etc.) (3) }\end{array}$ & 14 & $70 \%$ & $13 \%$ \\
\hline Regional level & $\begin{array}{c}\text { Regional } \\
\text { administration } \\
\text { of transfer } \\
\text { organizations }(5 \\
\text { )Local } \\
\text { establishment } \\
\text { of national } \\
\text { administration } \\
\text { (ANVAR) (1) }\end{array}$ & 6 & $30 \%$ & $5 \%$ \\
\hline Total & & 20 & $100 \%$ & $18 \%$ \\
\hline
\end{tabular}

Let's remark that here are only the cases when institutional organizations are at the origin of the cooperations and not all of the cases when institutions where involved at one time or another to finance or to do something else in the cooperation. For example, in the seventies years, "the Direction générale de la recherche scientifique et technique" (DGRST) financed research projects only if they involved an association between a laboratory and a firm. This politic resulted in a number of cooperations.

\subsection{3. "Market" logic}

The third kind of connection $(42,38 \%)$ doesn't involve an external organization neither a chain of personal ties. It can result of the initiative of a researcher or a firm executive that 
seeks a partner by using formal means (reading scientific journals, consulting of data bases, etc.). When he found him, he will contact him to propose a meeting or a demonstration. The cooperation can also result from a organized meeting (congress, colloquium). The difference with the institutional connection is the number of people that attend the meeting. While in the institutional connection, the groups are small and people have to work together, in a congress, there are much more attending people and the future partners have to choose to contact each other. We also count as market logic, the kind of story when the connection result from a student getting a training period in a firm by using formal means.

\section{"Market" connections}

\begin{tabular}{|l|c|c|c|}
\hline $\begin{array}{l}\text { Categories of } \\
\text { market } \\
\text { connections }\end{array}$ & Number & $\begin{array}{c}\text { Proportion of } \\
\text { market } \\
\text { connections }\end{array}$ & $\begin{array}{c}\text { Proportion of all } \\
\text { connections } \\
\text { (among } 110 \text { coded } \\
\text { stories) }\end{array}$ \\
\hline $\begin{array}{l}\text { Publications, } \\
\text { reputation }\end{array}$ & 22 & $52 \%$ & $20 \%$ \\
\hdashline $\begin{array}{l}\text { Congress, } \\
\text { meetings }\end{array}$ & 13 & $31 \%$ & $12 \%$ \\
\hline $\begin{array}{l}\text { Training periods } \\
\text { market, } \\
\text { intermediaries }\end{array}$ & 7 & $17 \%$ & $6 \%$ \\
\hline Total & 42 & $100 \%$ & $38 \%$ \\
\hline
\end{tabular}

\subsection{Proximity effects can be explained by embeddedness or cooperations in personal networks, especially in professional ties}

We are now able to table connection logics with the local or non local character of the cooperations. 


\section{Connection logics and et partners regions}

\begin{tabular}{|c|c|c|c|c|}
\hline $\begin{array}{l}\text { Connection } \\
\text { logicsPartners } \\
\text { regions }\end{array}$ & Networks & Institutions & Market & Total \\
\hline $\begin{array}{l}\text { Local } \\
\text { cooperations(th } \\
\text { e firm is in the } \\
\text { same region } \\
\text { than the } \\
\text { laboratory) }\end{array}$ & $24(60 \%)$ & $8(20 \%)$ & $8(20 \%)$ & $40(36 \%)$ \\
\hline $\begin{array}{l}\text { The firm is in } \\
\text { Paris region }\end{array}$ & $17(41 \%)$ & $7(17 \%)$ & $17(42 \%)$ & $41(37 \%)$ \\
\hline $\begin{array}{l}\text { The firm is in } \\
\text { another region } \\
\text { or another } \\
\text { country }\end{array}$ & $7(24 \%)$ & $5(17 \%)$ & $17(59 \%)$ & $29(27 \%)$ \\
\hline Total & $48(44 \%)$ & $20(18 \%$ & $42(38 \%)$ & $110100 \%$ \\
\hline
\end{tabular}

$($ Khi2 $=11,89, \mathrm{p}=0,018)$

These results suggest clearly that proximity effects can be explained by the embeddedness in local personal networks. However, we must insist that if the correlation is very significant, one must not make a confusion between local cooperations and networks logic of connection, since this logic applies for a great part to non local cooperations. The relative importance of network logic of connection with parisian firms can be explained by importance of the parisian labor market for engineers and PHD from provincial laboratories, school or universities.

Let's note that connection logics are not correlated with the laboratories regions, neither with the kind of firm (small or big), neither with the technical contents, neither with the length of the cooperations (see Bès \& Grossetti, 2000b). 
We consider that these data well sustain the first and second hypothesis, i.e. the explanation of proximity effects by spatial structure of personal networks and the relative embeddedness of cooperations between laboratories and firms in the teaching activity and in the labor market. We still have to examine the third hypothesis about the variation of action units.

\section{The research team level and some decoupling processes}

The analysis of the stories that we have collected shows that the most relevant group level is the research team having two to fifteen researchers, organized around a scientific leader, which was already seen by Michel Amiot (1996) or Terry Shinn (1980). On the firm's side, the level is almost the same, a specialized team in a big establishment, the direction team and some engineers in a small enterprise. One can observe at this level regular exchanges of information and handing over between people in research and development operations. We didn't always observed true teams or working groups in the laboratories and in the enterprises. Sometimes it is only a lonely researcher or engineer that cooperates, sometimes with the help of a student.

If we take into account the two levels of the individual and the team, we obtain four configurations that can exist at one time in a cooperation : 1) one researcher and one member of a firm ; 2) one researcher and an industrial team ; 3) a research team and one executive from a firm ; 4) a research team and an industrial team. In the three last cases, there can be, and there generally is, an intermediary person.

We can analytically distinguish four kinds of processes, always linked in real cases, that result in decoupling of the relation from the flow of interindividuals interactions. These processes can result in the sharing of contacts by a team and the making of a formal relation.

The first decoupling process, the "collectivization", is the result of the teams internal organization and of the organizational characteristics of the cooperation project itself. This can lead to a kind of task division, some persons becoming specialists in interface activities (contracts seeking, participation in scientific associations, etc.). Traditionally, these tasks were assumed by the scientific leader, altogether with the scientific management. This process, that we can call "collectivization" have its reciprocal, the personalization, when a researcher or an 
engineer, who have participated in a cooperation in a team, take it over until that if he would move to another laboratory, the cooperation would end. Almost half of the 19 teams that we studied have a real collective organization. The other can be totally individualized or collective only for a part.

The second decoupling process, the "formalization", well documented by Cassier (1997), is the legal framework of the contract that define the resources sharing and what everyone is supposed to do. The contract contributes to frame individual action and collective action (from the team, the laboratory, the CNRS, the firm, the industrial group). A great part of the contracts negotiation is dedicated to the making of internal agreements (with the legal department or the financial department for example) on the basis of the first agreement between the two cooperating teams.

The third process, that we can call "materialization", is the action of all the technical devices or materials that allow common work : modeling, making of a specific software, instrumentation, specific data, materials, intermediary reports. These material intermediates allow the outmatching of permanent interaction between participants and are necessary to the task division. It is an important dimension of scientific and technical work, well documented in the works of Callon (1989), Latour (1994) and other researchers following this line of analysis.

These three processes, that we have found in our stories, are well analyzed by the sociology of organizations or the innovation studies. We would like now to insist on a fourth process that we found being absolutely central in the cooperation between laboratories and enterprises and that is much less often mentioned in the studies of these cooperations. This process, that we call "personification", is the involving in the cooperations of particular persons that embody for a time the relation between a laboratory and a firm : students doing training periods in the firm, PHD students working on common topics with a grant from the firm, researchers being on transfer to a firm or on the contrary, firm members being for a time in the laboratory. These people belong for a time to both the organizations. One could say that they belong to the cooperation organization and to the cooperation project. In more than 9 cases on 10, the cooperation is based on the work of these intermediate people. 
Like material intermediates, human intermediates contribute to decouple the relations from the involved organizations. In the same time, as far as students tend to be recruited by the cooperating firms and as people on transfer keep relations with their former co-workers, this fourth process results also in an embeddedness in personal networks and can contribute to take down the studied decouplings made by the three other processes.

\section{Conclusion}

These results can reinforce the theoretical framework that we have presented at the beginning of this paper. The interest of this framework is to define several different processes of embeddedness processes involving different units of action. The proximity effects explanation involves embeddedness of organizations relations in personal networks, embeddedness of personal networks in different spheres of activity and, as a result of these two processes, the embeddedness of particular sphere of activity in other spheres (here particularly the embeddedness of cooperations between firms and laboratories in the teaching activities and the labor market)

The analysis of our stories shows the relevance of two levels of action for the understanding of cooperations between laboratories and firms : the individuals and the small teams, with frequent move of initiative from one to another. In that particular case, it is difficult to make models with only one level of action without studying the specific effects of the other level.

\section{References}

Amiot, M. (1996): Le laboratoire entre équipes et réseaux. poids des techniques et conflits de légitimités. Archives Européennes de Sociologie 37:2, 271-319

Audretsch, D.B., Feldman, M.P. (1996): R\&D Spillovers and fhe Geography of Innovation and production. The American Economic Review 86:3, Juin, 630-640

Bès, M.-P., Grossetti, M. (2000): Collaboration trajectories between CNRS research laboratories In Engineering Sciences and Firms : genesis and evolution, European Association For Evolutionary Political Economy Conference, November 2-5, Berlin 
Callon, M. (1998): Introduction : the Embeddedness of economic Markets in Economics. In : Callon, M. (Ed.): The Laws Of The Markets. Blackwell Publishers/The Sociological Review. Oxford, U.K, 1-57

Callon, M. (1999): Une contribution de la sociologie à l'analyse des externalités. essai sur la notion de cadrage/débordement., In: Foray, D., Mairesse, J. (Eds.): Innovations et Performance. Editions EHESS, Paris, 399-432

Cassier, M. (1997): Compromis institutionnels et hybridations entre recherche publique et recherche privée. Revue d'économie Industrielle 79, 191-212

Estades, J., Joly, P-B., Mangematin, V. (1996): Dynamique des relations industrielles dans les laboratoires d'un grand organisme public de recherche : coordination, apprentissage, réputation et confiance. Sociologie du Travail 3, 391-408

Feldman, M. (1994): The Geography of Innovation. Kluwer, Dordrecht

Granovetter, M. (1985): Economic action and social structure : the problem of embeddedness. American Journal of Sociology, 91, 481-510

Granovetter, M., Swedberg, R. (Eds) (1991): The Sociology of Economic Life. Westview Press, Boulder, San Francisco, Oxford

Grossetti, M. (1995): Science, Industrie et Territoire. Presses Universitaires du Mirail, Coll. Socio-Logiques, Toulouse

Grossetti, M. (1998): La proximité en Sociologie : une réflexion à partir des systèmes locaux d'innovation. In: Bellet, M., Kirat T., Largeron C. (Eds.): Approches mutiformes de la proximité. Coll. Interdisciplinarité et nouveaux outils, Hermès, Paris, 83-101

Grossetti, M. (2001): Les effets de proximité spatiale dans les relations entre organisations : une question d'encastrements, Espaces Et Sociétés 101-102 (forthcoming)

Latour, B. (1994): «Une Sociologie sans objet ? Remarques sur l'interobjectivité ». Sociologie du Travail 4, 587-607

Powell, W.W., Brantley, P. (1992): Competitive cooperation in Biotechnology : Learning through Networks ?. In: Nohria, N., Eccles, R.G. (Eds): Networks and Organizations : Structure, Form and Action. Boston, Harvard Business School Press, 366-394

Powell, W.W. (1994): Interorganizational Relations. In: International Encyclopedia of Business and Management. Routledge, Londres.

Saxenian, A. (1994): Regional Advantage. Harvard University Press.

Shinn, T. (1980): Division du savoir et spécificité organisationnelle. Revue française de Sociologie, 21:1, 3-35.

White, H.C. (1992): Identity and Control. A Structural Theory of Action. Princeton University Press, Princeton.

Zucker, L.G., Darby M.R., Armstrong, J. (1994): Intellectual Capital and the Firm : the Technology of Geographically Localized Knowledge Spillovers. NBER Working Paper Series, Working Paper 4946, NBER, Cambridge, Mass. 

We used 7 categories of contents : measures, characterization ; modeling or improvement of a process or
system ; adapting a system to new components, adaptation a system to a new domain of application ;
technological watching. 